\title{
Litter cover of the invasive tree Melaleuca quinquenervia influences seedling emergence and survival
}

\author{
Min B. Rayamajhi", Paul D. Pratt, Philip W. Tipping, Ted D. Center \\ Invasive Plant Research Laboratory, United States Department of Agriculture, Fort Lauderdale, USA; \\ *Corresponding Author: min.rayamajhi@ars.usda.gov
}

Received 15 May 2012; revised 25 June 2012; accepted 23 July 2012

\begin{abstract}
Exotic tree Melaleuca quinquenervia (melaleuca) deposits large quantities of slowly decomposing litter biomass that accumulates over time and covers forest floors in its adventive habitats in Florida (USA). Herein, we assessed the influence of melaleuca litter cover, seed addition, and seeding date on seedling emergence and survival. The assessment was conducted by manipulating litter cover and seed inputs of melaleuca and two native species at different dates in two soil types. Litter cover was either removed or left in place in organic and arenaceous soils within melaleuca stands. Each of the three treatment plots were seeded with melaleuca, wax myrtle or sawgrass, while the fourth plot was not seeded and served as the control. Seedlings were counted at 2-wk intervals to determine cumulative seedling emergence and survival during the experimental period. The experiment was repeated four times within a year. Soil type did not influence seedling emergence of all three species but influenced survival of wax myrtle. Litter removal increased the emergence of melaleuca, sawgrass, and wax myrtle and increased the survival of melaleuca. Seed addition increased the emergence and survival of sawgrass and wax myrtle but made no difference for melaleuca. Seeding during the periods of high soil moisture content had positive effects on the emergence and survival of melaleuca, wax myrtle, and sawgrass seedlings. These findings are deemed useful in planning active restoration for melaleuca invaded sites.
\end{abstract}

Keywords: Disturbance; Exotic Tree; Invasive Plant; Leaf Litter; Melaleuca quinquenervia; Seedling

Emergence; Seedling Survival

\section{INTRODUCTION}

The general role of plant litter in community structure and function has been reviewed by Facelli and Pickett [1-3] and Xiong and Nilsson [4,5]. Accumulation of plant litter biomass on forest floors affects community structure in ecosystems [6] by influencing seedling emergence and establishment [7]. In general, litter biomass affects seeds in forest floors by restricting them to the litter surface thereby obstructing contact with underlying soils, cutting off light, or altering seed temperature [7-9]. Germination of species with large seeds is usually not affected by litter cover, while smaller seeded species may experience reduced germination [10]. Litter accumulation however, has less effect on germination and seedling establishment of shade tolerant species [11]. The biomass of litter may affect seeds physically by burying them, or affect them chemically by adding nutrients or phytotoxins to the soil. Biological effects of litter biomass may include the addition of diaspores that serve as the plant-dispersal units [4]. High litter deposition by a dominant plant species can modify competition, suppress competing plants, and lower plant species richness [5,12-14].

Invasive plants are capable of modifying environments, including soils on which they persist, in ways that increases their fitness and facilitates invasion [15]. These modifications can displace native plants and lead to the development of invasive monocultures [5]. Soil systems are altered by the litter type, amount, rate of decomposition, effects on soil $\mathrm{pH}$, release of nutrients from litter, and nutrient-induced changes in soil biota $[15,16]$. Despite these negative effects of dominant invasive plants, published reports documenting the direct impact of exotic plant litter biomass on the emergence and survival of seedlings are rare. Melaleuca quinquenervia (Cav.) Blake is of Australian origin (hereafter referred to as "melaleuca") and was introduced into south Florida (USA) during the early 1900s [17]. This exotic tree can deposit large amounts of litter annually to the forest floor of in- 
vaded areas $[18,19]$. Melaleuca leaf litter in sawgrass marshes decomposes more slowly than sawgrass leaf litter under the same environmental regime [19]. This slow decomposition rate, coupled with high annual litterfall (up to $12 \mathrm{Mg} \cdot \mathrm{ha}^{-1} \cdot \mathrm{yr}^{-1}$ ) leads to the accumulation of a large amount of litter mass (up to $25 \mathrm{Mg} \cdot \mathrm{ha}^{-1}$ at any given time) on forest floors, which may limit recruitment of native plants in melaleuca dominated stands $[18,19]$.

More recently, the number and size of canopy openings in mature melaleuca stands have increased following attack by released natural enemies such as Oxyops vitiosa Pascoe (weevil), Boreioglycaspis melaleucae Moore (psyllid), and an adventive rust fungus Puccinia psidii G. Winter. These agents have caused significant tree-crown thinning and mortality of melaleuca seedlings, saplings and even mature trees [20-23]. This plant mortality has resulted in a short-term increase in the amounts of accumulated melaleuca litterfall. The density of released and adventive natural enemies in south Florida is generally highest during late fall through early summer, which coincides with milder temperatures and emergence of new foliage (Rayamajhi, personal observation).

General attributes of invasive plants include high reproductive capacity (precocity, self-compatibility, copious/frequent flowering, prolific seed production, smaller seeds that lack dormancy, capacity for vegetative multiplication, etc.), superior competitive ability, morphological or physiological plasticity, and rapid growth potential [24-27]. Melaleuca possesses many of these invasive traits in its adventive range in Florida [28-30]. One such trait is the ability to produce and retain large quantities of seeds (up to $550 \mathrm{~kg} \cdot \mathrm{ha}^{-1}$ in mature stands) in serotinous woody capsules for several years [22], which provides a sustained input of seeds to the forest-floor. Under water-saturated conditions, most melaleuca seeds germinate within 10 days, although a small fraction may remain dormant for an extended time [30]. All seeds at the soil surface or buried as deep as $5-\mathrm{cm}$ in water-saturated organic soils germinate within 18 months, but a few seeds buried in arenaceous (predominantly sandy) soils remain dormant over 28 months [31]. Ground fires that scorch vegetation and expose mineral soils stimulate the emergence of melaleuca seedlings (Center, unpublished data). Similarly, animals such as armadillos and wild pigs disturb the leaf litter while searching for food, which also appears to stimulate seedling emergence (Rayamajhi, personal observation). These observations suggest that melaleuca litter may impede seedling emergence and establishment of both exotic and native plants but this has not been tested in the field. In addition, there are no data on potential interactions between the timing of litter removal and seedling emergence, as well as seedling survival in mature melaleuca stands. Therefore, the objectives of this current study were to assess the influence of 1) melaleuca litter cover, 2) seed addition, 3) soil type, and 4) seeding date on the emergence and survival of seedlings within mature stands of melaleuca in southern Florida. Information obtained may prove useful to land managers in active restoration of melaleuca invaded areas.

\section{MATERIALS AND METHODS}

\subsection{Study Sites}

Two sites were used for this study, both located in southern Florida. The Broward County site was located between N26 02'59.39", W080 26'22.71" and N26 $02^{\circ}$ '58.68', W080 $26^{\prime} 22.68^{\prime \prime}$ and the Collier County site, in the Picayune Strand State Forest, was located between N26 06'28.10", W081 38 $38^{\prime} 19.77^{\prime \prime}$ and N26 06'27.43", W081 $38^{\prime} 19.68^{\prime \prime}$. These sites represent two physically separated geographic areas with starkly different soils with the Broward County site consisting of organic soil and the Collier County site consisting primarily of arenaceous soils. General soil types, organic matter content, and vegetation composition of the Broward and Collier County sites are described in Rayamajhi et al. [19]. Within each site a mature melaleuca stand was chosen where melaleuca trees were sparse. As reported in Rayamajhi et al. [19] the $\mathrm{pH}$, water holding capacity, total carbon, total nitrogen and carbon/nitrogen ratios in the upper $10 \mathrm{~cm}$ of the organic soils in the areas of the current study site was $7.7( \pm 0.1), 512.6( \pm 41.4), 407.4( \pm 9.9)$, $27.3( \pm 2.5)$, and $15.1( \pm 1.0)$ respectively; similarly, the soil $\mathrm{pH}$, water holding capacity, total carbon, total nitrogen and carbon/nitrogen ratios in the upper $10 \mathrm{~cm}$ of the arenaceous soils was $6.0( \pm 0.0), 65.9( \pm 13.7), 51.3( \pm 12.9)$, $2.5( \pm 0.6)$ and $20.0( \pm 1.7)$, respectively. These sites are typical of wetlands in Florida where Cladium jamaicense Crantz (sawgrass), Morella cerifera (L.) small (wax myrtle) and other native plants are being replaced by melaleuca.

\subsection{Seed Source for Experiments}

Melaleuca seeds used in this study were collected from Broward County, Florida in 1997 and were stored at room temperature $\left(22^{\circ} \mathrm{C}-25^{\circ} \mathrm{C}\right)$. Sawgrass and wax myrtle seeds used in this experiment were collected, during 2003-2004 from Broward County and Picayune State Forest, Collier County, FL, respectively and were stored in the same as melaleuca seeds. The glasshouse, the mean seed germination rates (of the seeded plant species) as tested in the commercial potting soil (PROMIXPGX, Premier Horticulture Inc., 127 South $5^{\text {th }}$ Street, Quakertown, PA 18951) were $14.3 \% \pm 4.8 \%$ (range $4 \%$ $20 \%$ ), $23.5 \% \pm 10.1 \%$ (range $11 \%-44 \%$ ), $17.8 \% \pm 4.4 \%$ (range $14 \%$ - 26\%), for melaleuca, wax myrtle and saw- 
grass, respectively at the onset of the current study.

\subsection{Litter Cover and Soil Moisture}

The amount of litter cover in research plots was estimated by collecting four litter (leaf and twig $\leq 1.0 \mathrm{~cm}$ diameter) samples from each of the sites representing two soil types at the onset of each experiment. Litter was air-dried at $70^{\circ} \mathrm{C}$ until a constant weight was achieved and the dry weight of all samples was individually recorded. From these data the litter biomass was determined as grams of dry weight $/ \mathrm{m}^{2}$.

\subsection{Experimental Design}

This experiment was performed over four, 12-wk periods during 2005-2006 using split-split plot design. To ensure that no seeds dispersed into the plots or intentionally introduced seeds were washed away during the experiment, we constructed sheet metal frames: each 30.0 $\mathrm{cm} \times 30.0 \mathrm{~cm}=0.09 \mathrm{~m}^{2}(20 \mathrm{~cm}$ height $)$ with four equally sized compartments, labeled A, B, C and D (Figure 1). The frames were pressed down ca $2 \mathrm{~cm}$ into the soil through the melaleuca litter cover. Edges of the frames were sharp enough to cut through smaller twigs and leaf litter. We installed two frames side by side (see Figure 1) to minimize microenvironment differences for variables like soil type, elevation, and litter depth. Litter was removed from four plots within one frame to expose the underlying mineral soil (hereafter referred as the "litter removed" plot) while another identical frame was left unmodified (hereafter referred as the "litter covered" plot), these frames served as whole plots (litter cover). Into three of the four compartments in each frame we added (spread evenly) seeds of melaleuca, wax myrtle or sawgrass at a rate of 2222 seeds $/ \mathrm{m}^{2}$. No seeds were added to the fourth compartment which served as the "control" treatment. These seed species plus control treat-

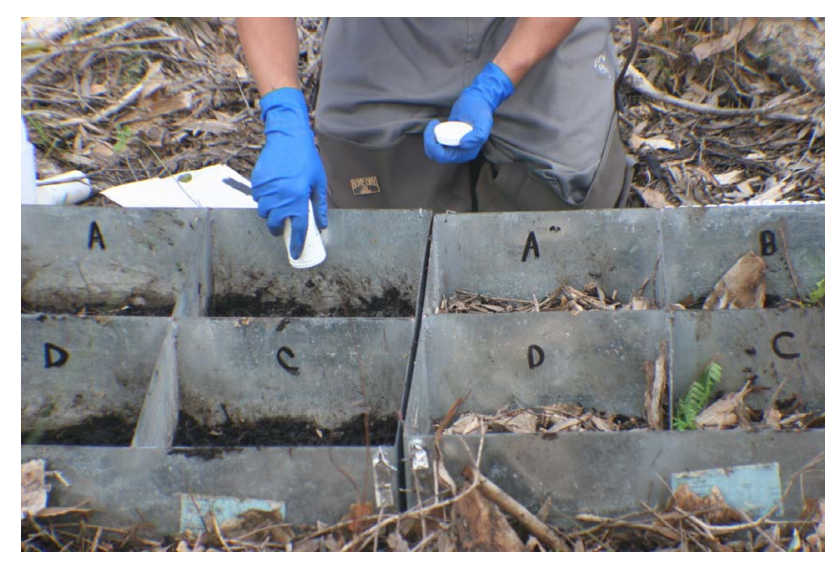

Figure 1. Metal frames used to create litter-removed and litter covered compartments $\left(0.09 \mathrm{~m}^{2}\right.$ plots $)$; Note the composition of melaleuca litter (leaves and small twigs). ment served as sub-plots and were randomized within the frame. Each pair of litter removed and litter covered frames containing sub-plots were replicated three times per site (soil type) and were considered sub-subplots. The effects of seeding date were determined by temporally repeating the whole experiments four times (April, July and November of 2005, and February of 2006) in approximately 3-month interval. For each seeding date, the frames were located in different places within the study site and the treatment plots within frames were randomized. After seeding, melaleuca litter accumulating on litter removed and litter covered plots was left in situ during 12-wk experimental period to reflect the natural field conditions following seeding. Each experiment was monitored for a 12-wk period.

Seedling emergence and survival was recorded at 2-wk intervals during each of the 12-wk periods and total emergence and survival of seedlings during the experimental period was calculated. A seedling was counted as emerged after its cotyledons expanded and the seedling was sufficiently visible on the surface of the mineral soil or litter as described in Hastwell and Facelli [32]. Each seedling was marked by placing a toothpick next to it to avoid recounting at the next sample. The total number of seedlings emerged during the each 2 -wk interval were summed to calculate the total seedling emergence during the experimental period. Similarly, the total live seedlings at the end of the sixth 2-wk interval were recorded; these numbers represented the total seedling survival at the end of the experimental period. Only three plant species of interest, namely melaleuca, wax myrtle, and sawgrass were documented by species; the remaining plants were counted and grouped into broad taxonomic groups (e.g., monocots and dicots). In this study, only melaleuca, sawgrass, and wax myrtle seedlings were included in the analysis. It should be noted, however, that densities of the other species were low in all plots and assumed to have no negative competitive affect on the three study species.

\subsection{Data Analysis}

Data were analyzed with a General Linear Model (PROC GLM) in SAS [33]. Cumulative seedling emergence was obtained by adding the total number of plants by species from each of the six 2-wk evaluations during the 12-wk experimental period. However, the seedling survival data represented only the percentage of plants alive at the end of the respective 12-wk experimental period. We analyzed data using mix model ANOVA in which the effects of the independent variables (soil type, litter cover and seeding date) on dependent variables (seedling emergence and survival) were considered random. Full model multivariate analysis showed significant main effects, and two- and three-way interactions 
(among independent variables) for the emergence and survival of some species (Table 1). This was simplified by carrying out further ANOVA and mean separations by litter cover and seeding date within respective soil type.

The main effect of $M$. quinquenervia, $M$. cerifera and C. jamaicense seed addition on the dependent variable (seedling emergence of these species) was considered fixed while performing simple ANOVA. In this case, the number (cumulative) of seedlings in seeded plots was compared with the number of seedlings in the control plots which were not seeded with any of the three species.

The survival percentages were determined for each of the three species based on the total number of emerged seedlings (by species) within the experimental period and the seedlings that survived to the end of the corresponding experimental period. These percentage data on survival rates were arcsine transformed prior to analysis; however, actual percentages are presented in tables and figures. The mean separations for all the response variables were carried out using LSD procedure.

Table 1. Full model analysis of variance showing the effects of the soil type, litter cover, and seeding date on seedling emergence (total during the experimental period) and survival at the end of the experiments.

\begin{tabular}{ccccccc}
\hline Source/variables & \multicolumn{2}{c}{ Melaleuca } & \multicolumn{2}{c}{ Wax-myrtle } & \multicolumn{2}{c}{ Sawgrass } \\
Emergence & $F$ & $P$ & $F$ & $P$ & $F$ & $P$ \\
\hline Emergence & & & & & & \\
TRT1 & 2.5 & 0.116 & 0.09 & 0.766 & 1.63 & 0.203 \\
TRT2 & 105.13 & $<0.001$ & 4.11 & 0.008 & 4.06 & 0.008 \\
TRT3 & 94.81 & $<0.001$ & 4.37 & 0.038 & 3.34 & 0.069 \\
TRT1 $\times$ TRT2 & 23.96 & $<0.001$ & 2.67 & 0.049 & 0.39 & 0.76 \\
TRT1 $\times$ TRT3 & 1.35 & 0.247 & 0.34 & 0.561 & 1.91 & 0.169 \\
TRT2 $\times$ TRT3 & 13.46 & $<0.001$ & 0.91 & 0.435 & 1.06 & 0.366 \\
TRT1 $\times$ TRT2 $\times$ & 8.55 & $<0.001$ & 1.04 & 0.378 & 0.56 & 0.639 \\
TRT3 & & & & & & \\
Survival & & & & & & \\
TRT1 & 1.01 & 0.316 & 5.64 & 0.027 & 3.21 & 0.086 \\
TRT2 & 161.38 & $<0.001$ & 3.75 & 0.027 & 0.2 & 0.819 \\
TRT3 & 9.92 & 0.002 & 1.51 & 0.232 & 0.16 & 0.689 \\
TRT1 $\times$ TRT2 & 16.9 & $<0.001$ & 1.37 & 0.277 & 1.59 & 0.225 \\
TRT1 $\times$ TRT3 & 6.62 & 0.011 & 0.17 & 0.686 & 0.06 & 0.815 \\
TRT2 $\times$ TRT3 & 0.98 & 0.405 & 2.3 & 0.125 & 0.31 & 0.584 \\
TRT1 $\times$ TRT2 $\times$ & 2.88 & 0.037 & 2.5 & 0.129 & 3.97 & 0.058 \\
\hline TRT3 & & & & & & \\
\hline
\end{tabular}

${ }^{1}$ TRT1 = Soil types, TRT2 $=$ Seeding date, TRT3 $=$ Litter cover. DF $=1,3$ and 1 for soil types, seeding date, and litter cover, respectively.

\section{RESULTS}

\subsection{Accumulated Litter and Soil Moisture}

The mean $( \pm \mathrm{SE})$ amount of litter in plots at the organic soil site $\left(1.95 \mathrm{~kg} / \mathrm{m}^{2} \pm 0.09 \mathrm{~kg} / \mathrm{m}^{2}\right)$ was greater $(F=$ $12.01 ; P=0.0016, N=16)$ than in plots at the arenaceous soil site $\left(1.45 \mathrm{~kg} / \mathrm{m}^{2} \pm 0.11 \mathrm{~kg} / \mathrm{m}^{2}\right)$. Overall moisture content in the top 5 -cm soil-layer during the experimental period (Figure 2) was higher at the site with organic soils (range: $75.4 \% \pm 1.07 \%-78.00 \% \pm 0.70 \%$ ) than at the site with arenaceous soil (range: $13.40 \% \pm$ $3.60 \%-34.7 \% \pm 2.00 \%$ ). Soil moisture content in organic soils was higher during July 2005-February 2006 while in arenaceous soils moisture content increased during July 2005-October 2005 and declined during November 2005-May 2006.

\subsection{Litter Cover}

Overall, accumulated litter cover on the soil surface markedly reduced seedling emergence $(F=18.04, P<$ $0.0001)$. This trend was consistent between soil types (Tables 1 and 2, Figures 3 and 4) except for the emergence of sawgrass seedlings at the arenaceous site, which was not influenced by litter cover (Figure 4(a)). Litter cover did not influence survival of the sawgrass or wax myrtle seedlings that emerged (Tables 1 and 2, Figures 3(b) and 4(b)), although there is evidence to suggest that melaleuca seedlings in organic soils experienced greater survival rates in the absence of litter cover (Tables 1 and 2, Figure 3(b)).

\subsection{Soil Types}

Soil type did not affect seedling emergence of any of the three species tested (Table 1, Figure 5 (a)).

Seedling survival of melaleuca and sawgrass was not affected by soil type while survival of wax myrtle increased in arenaceous soils (Figure 5 (b)).

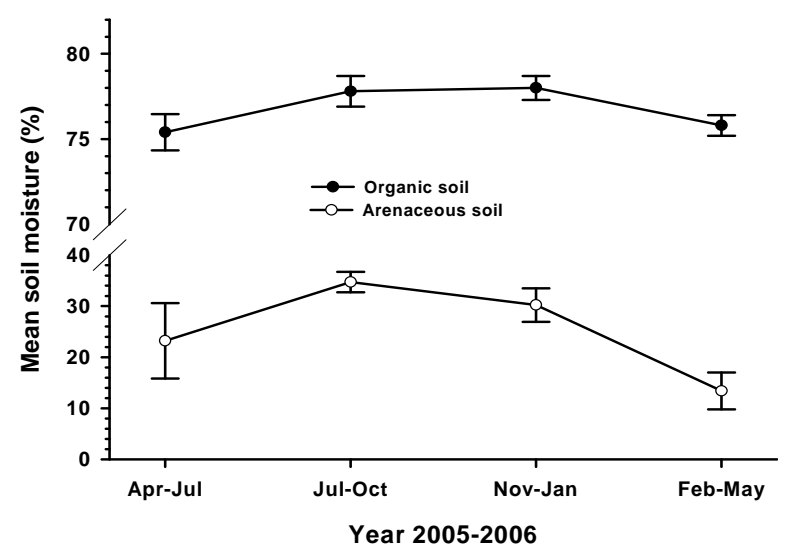

Figure 2. Mean soil moisture content ( $\%$ by weight) during four 3-mo periods during 2005-2006. 

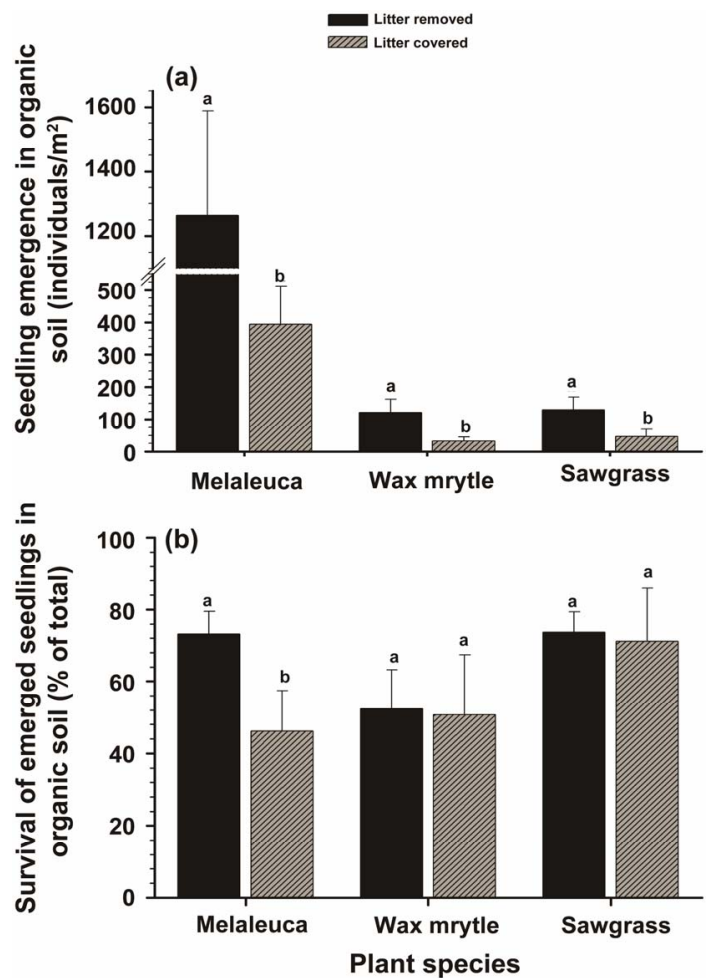

Figure 3. Effects of litter cover on the emergence and survival of seedlings in organic soils: (a) Seedling emergence; (b) Survival of emerged seedlings. Different letters associated with vertical columns within species/groups indicate significant difference between the "litter removed" and "litter covered" treatments LSD test $(P=0.05)$.

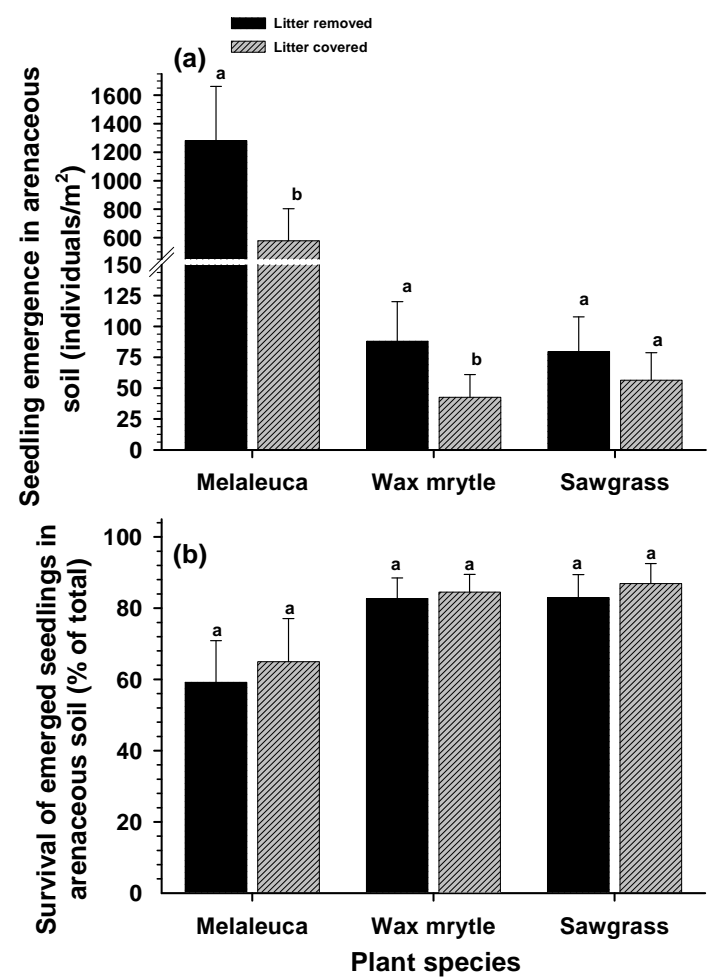

Figure 4. Effects of litter cover on the emergence and survival of seedlings in arenaceous soils: (a) Seedling emergence; (b) Survival of emerged seedlings. Different letters associated with vertical columns within species/groups indicate significant difference between the "litter removed" and "litter covered" treatments as per LSD test $(P=0.05)$.

Table 2. Analysis of variance (ANOVA) showing the main effects of the seeding date and litter cover on the seedlings emergence (cumulative over experimental period) and survival under mature melaleuca stands.

\begin{tabular}{|c|c|c|c|c|}
\hline \multirow[b]{3}{*}{ Plants/variables } & \multicolumn{4}{|c|}{ Soil types } \\
\hline & \multicolumn{2}{|c|}{ Organic soils } & \multicolumn{2}{|c|}{ Arenaceous soils } \\
\hline & F & $P$ & F & $P$ \\
\hline \multicolumn{5}{|l|}{ Seeding date } \\
\hline Emergence & 7.05 & 0.0022 & 24.71 & $<0.0001$ \\
\hline Survival & 5.86 & 0.0061 & 51.4 & $<0.0001$ \\
\hline \multicolumn{5}{|l|}{ Wax myrtle } \\
\hline Emergence & 3.85 & 0.0261 & 28.41 & $<0.0001$ \\
\hline Survival & 1.59 & 0.2526 & 4.91 & 0.0538 \\
\hline \multicolumn{5}{|l|}{ Sawgrass } \\
\hline Emergence & 26.07 & $<0.0001$ & 31.4 & $<0.0001$ \\
\hline Survival & 1.48 & 0.274 & 0.03 & 0.8681 \\
\hline \multicolumn{5}{|l|}{$\begin{array}{l}\text { Litter cover } \\
\text { Melaleuca }\end{array}$} \\
\hline Emergence & 11.62 & 0.0029 & 10.72 & 0.004 \\
\hline Survival & 4.15 & 0.0575 & 0.19 & 0.6698 \\
\hline \multicolumn{5}{|l|}{ Wax myrtle } \\
\hline Emergence & 6.24 & 0.0218 & 7.09 & 0.0154 \\
\hline Survival & 0.08 & 0.7851 & 0.15 & 0.7103 \\
\hline \multicolumn{5}{|l|}{ Sawgrass } \\
\hline Emergence & 14.75 & 0.0011 & 2.13 & 0.1607 \\
\hline Survival & 0.04 & 0.8495 & 0.26 & 0.6231 \\
\hline
\end{tabular}

$\mathrm{DF}=1$ for both emergence and survival parameters. Data from both litter-removed and litter-covered plots within soil type was pooled for analysis. 

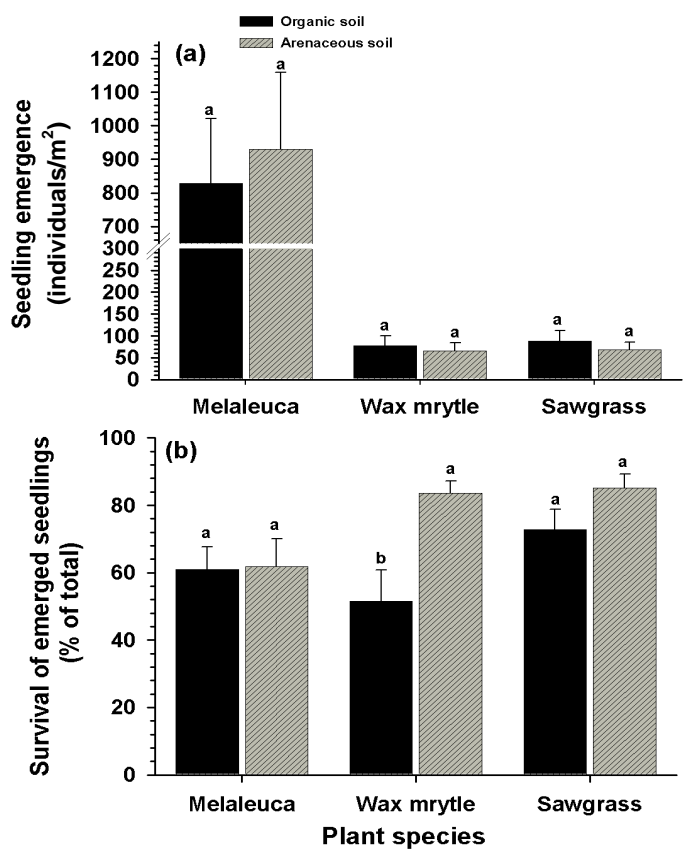

Figure 5. Effects of soil types on seedling emergence and survival by seeded species and overall groups: (a) Emergence (cumulative over three month period); (b) Survival (\% of the cumulative total number of seedlings emerged) at the end of the experimental period. Different letters associated with vertical columns within species/groups indicate significant difference between organic and arenaceous soil types as per LSD test $(P=0.05)$.

\subsection{Seed Addition}

The emergence of melaleuca seedlings in plots seeded with melaleuca was not different than in the unseeded control plots (Table 3). In contrast, wax myrtle and sawgrass seedling emergence in seeded plots was significantly greater than in control plots (Table 3 ). These trends were similar in both organic and arenaceous soils (Table 3).

Table 3. Analysis of variance (ANOVA) comparing the main effects between seed added and control (seed not added) treatments $(\mathrm{DF}=1, N=24)$ on seedling emergence of the three plant species of interest.

\begin{tabular}{|c|c|c|c|c|}
\hline \multirow{2}{*}{$\begin{array}{l}\text { Independent } \\
\text { variables }\end{array}$} & \multirow{2}{*}{$F$} & \multirow{2}{*}{$P$} & \multicolumn{2}{|c|}{ Seedling emergence $\left(/ \mathrm{m}^{2}\right)$} \\
\hline & & & Seeded & $\begin{array}{c}\text { Unseeded } \\
\text { (control) }\end{array}$ \\
\hline \multicolumn{5}{|l|}{ Organic soils } \\
\hline Melaleuca & 0.28 & 0.577 & $829.2(191.4) \mathrm{a}^{1}$ & $699.1(151.9) \mathrm{a}$ \\
\hline Wax myrtle & 11.64 & 0.0014 & $77.8(22.5) \mathrm{a}$ & $0.93(0.93) b$ \\
\hline Sawgrass & 13.04 & 0.0008 & $88.0(23.9) \mathrm{a}$ & $1.39(1.39) \mathrm{b}$ \\
\hline \multicolumn{5}{|c|}{ Arenaceous soils } \\
\hline Melaleuca & 0.03 & 0.8652 & $930.1(228.0) \mathrm{a}$ & $874.5(232.1) \mathrm{a}$ \\
\hline Wax myrtle & 11.77 & 0.0013 & $65.3(18.7) \mathrm{a}$ & $0.93(0.93) b$ \\
\hline Sawgrass & 14.47 & 0.0004 & $68.06(17.8) \mathrm{a}$ & $0.5(0.5) b$ \\
\hline
\end{tabular}

${ }^{1}$ Mean number (cumulative) of emerged seedlings $/ \mathrm{m}^{2}$ within row with the same letters are not significantly different from each other as per LSD test $(P=0.05)$. Numbers in the parenthesis represent standard errors of the mean.

\subsection{Seeding Date}

The dates that seeds were added to the plots affected seedling emergence of all species in both organic and arenaceous soil types (Tables 1 and 2). In organic soils, seeding during July-October 2005 and November 2005early February 2006 produced the greatest seedling emergence for all three species, with melaleuca having the highest emergence among the three species (Figure 6(a)). Seedling emergence for all species was lower in organic soils except during the April-July 2005 seeding period (Figure 6(a)). The emergence of melaleuca, wax myrtle, and sawgrass seeds in arenaceous soils was greater when seeding commenced in November 2005-February 2006 (Figure 7(a)). There was no emergence of wax myrtle or sawgrass seedlings for the April-July 2005 and FebruaryMay 2006 seeding dates (Figure 7(a)).

The survival rate of melaleuca seedlings was different among seeding dates in both organic and arenaceous soils (Table 2). More melaleuca and wax myrtle seedlings survived in organic soils during April-July and July-October 2005 than in February-April 2006 (Figure 6(b)). In arenaceous soils, melaleuca survival rate was higher during multiple periods from April-October 2005

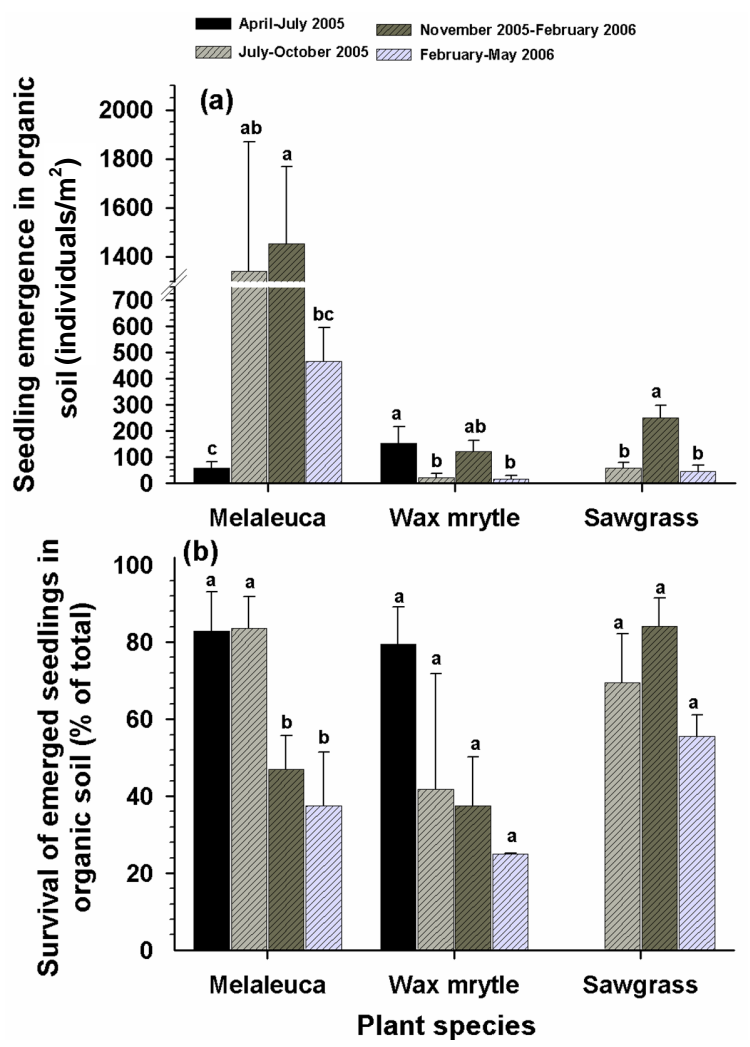

Figure 6. Influence of seeding date on the emergence and survival of seedlings in organic soils: (a) Seedling emergence; (b) Survival of emerged seedlings. Different letters associated with vertical columns within species/groups indicate significant difference among seeding dates as per LSD test $(P=0.05)$. 

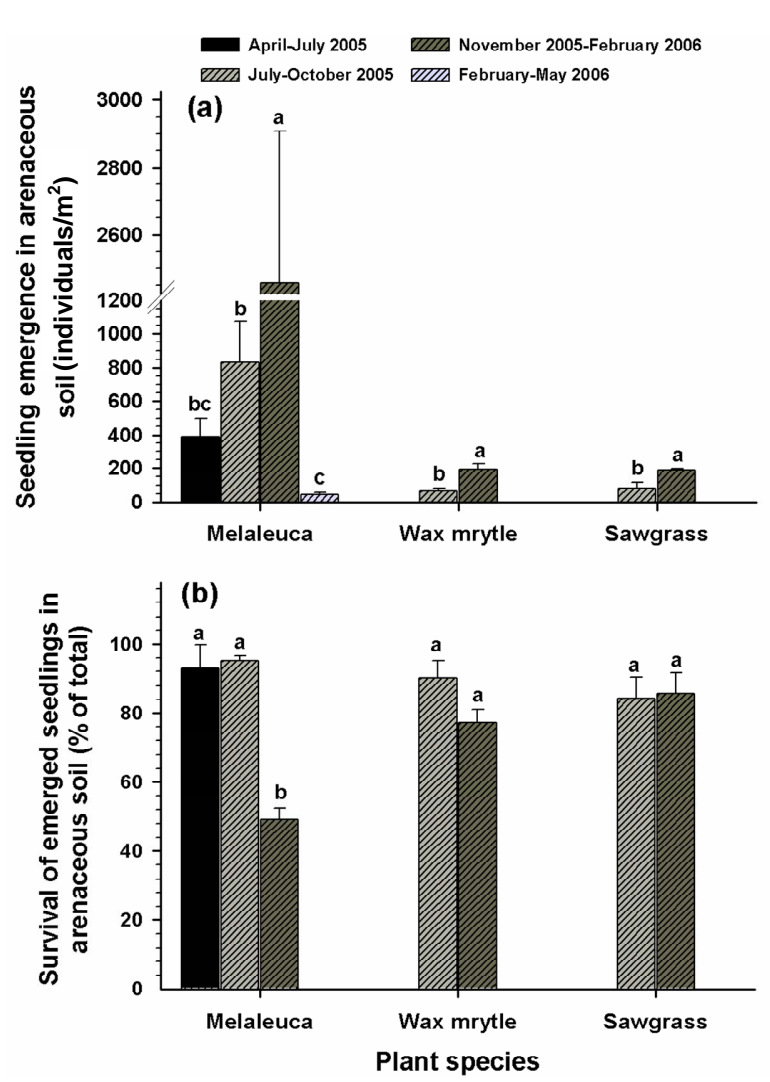

Figure 7. Influence of seeding dates on the emergence and survival of seedlings in arenaceous soils: (a) Seedling emergence; (b) Survival of emerged seedlings. Different letters associated with columns within species/groups indicate signifycant difference among seeding dates as per LSD test $(P=0.05)$.

but none survived during the February-April 2006. Sawgrass had similarly higher survival rates in both the July-October 2005 and November 2005-February 2006 seeding periods (Figure 7 (b)).

\section{DISCUSSION}

\subsection{Litter Cover}

Litter biomass has been implicated as a mechanism inhibiting seedling emergence of various plant species $[10,34,35]$. Melaleuca litter inhibited seedling emergence of all three plant species in our study; conversely, litter removal and exposure of mineral soils increased seedling emergence in both organic and arenaceous soils (Figures 3(a) and 4(a)) as has been reported in other systems as well [7,36]. Rasran et al. [37] found that litter removal and mowing stimulates emergence and establishment of the herbaceous plants Lotus pedunculatus Cav. and Silene flos-cuculi (L.) Clairv [37]. Similarly, litter removal stimulated Quercus seedling emergence and survival in mixed oak-pine forests [38] as well as emergence of woody seedlings in a xeric successional community [32]. In other systems, researchers have demonstrated de- creased seed germination and seedling emergence with increased litter cover for small-seeded species $[7,11$, 35,39-41].

Our study also showed that litter cover reduced survival of emerged seedlings of melaleuca whose seeds are relatively smaller [42]. We attribute this to inadequate carbohydrate reserves in the smaller seeds which do not allow development of adequate root systems capable of penetrating litter layers in order to contact mineral soils. The litter cover however had no affect on the seedling emergence of other species with larger seeds (e.g., sawgrass and wax myrtle) (Figures 3(b) and 4(b)). Similar probability of seed germination and seedling emergence in species with larger seeds like Chrysophyllum appeared to be independent of the amount of litter because larger seeds produce larger cotyledons and physically more robust seedlings, able to emerge from thick deposits of plant litter [11,41].

\subsection{Soil Type}

The majority of emerged seedlings in both organic and arenaceous soils of our study sites were melaleuca, which is a prolific seeder and exhibits enhanced seed longevity when buried up to $5-\mathrm{cm}$ beneath the soil surface [31]. Removing the litter increased seedling emergence perhaps by exposing formerly buried seeds to conditions more conducive to germination. A similar phenomenon has been reported by Reader [43] involving seedling emergence of six plant species where ground cover was removed to expose soil surface.

In the current study, survival rates of some plant species differed between organic and arenaceous soils types. For example, both wax myrtle and sawgrass had better survival rates in arenaceous soils. These results are consistent with the findings of others wherein emergence and survival of seedlings differed according to plant species and general soil attributes such as texture, temperature, conductivity, light and soil moisture $[44,45]$.

\subsection{Seed Addition}

Seed addition affected seedling emergence of some species but not others. For example, seed addition had no effect on the quantity of melaleuca seedling emergence which normally releases seeds from the canopy seed bank year round [31] and while maintaining a smaller soil seed bank [46]. These canopy-held and soil seedbank bound seeds in control plots probably accounted for the lack of difference in emergence between melaleuca seeded and unseeded control plots. On the other hand, the addition of wax myrtle and sawgrass seeds increased emergence of both species compared with the control. Normally, seed sources for both species are usually sparse under melaleuca stands. Additionally these plants 
flower and fruit annually and hold seeds until maturity, thereby maintaining no transitional seeds in the canopy and very little transitional soil seedbank if any. Therefore, seed addition had significant positive effect on seedling emergence in wax myrtle and sawgrass. Similar increases in seedling emergence following seed addition have been reported for some plant species in subhumid grasslands [47]. It's likely that rehabilitating sites formerly infested with melaleuca will require additional seed inputs of appropriate native species.

\subsection{Seeding Date}

Temporal effects of seeding were evident on seedling emergence and survival. In general, emergence was greater during July 2005 through February 2006 than during February through July 2005. This difference (Figures 6(a) and 7(a)) coincided with higher moisture content (Figure 2) in the soils during that period. A similar influence of the timing of litter removal on seedling emergence was reported by Hastwell and Facelli [32] and Wardle [48]. Regardless of the presence or absence of litter on the forest floor and soil type, melaleuca seedling emergence was highest among the three plant species examined. This suggests that additional melaleuca seeds entered plots either from seeds buried in arenaceous soils [31] or from canopy seed banks $[30,42]$. There was no emergence of sawgrass and wax myrtle seedlings in arenaceous soils from February through early July, which corresponds to relatively low moisture content in our the study sites (Figure 2). Higher number of seedling emergence of these two plant species in late July through February suggested the requirement of higher moisture level for seedling emergence for sawgrass and wax myrtle. This finding showed similar trends shown by a seasonal tropical forest in Panama with a majority (75\%) of seeds germinating within the first 3 months of the rainy season [49].

\section{CONCLUDING REMARKS}

Our study demonstrated that litter cover significantly inhibited the emergence of the seeds for all species tested, but that seedling survival remained unaffected in wax myrtle and sawgrass. Combination of litter removal and high soil moisture promoted greater seedling emergence but the effect on seedling survival was species dependent. In general, melaleuca litter removal from forest floors enhanced restoration efforts by facilitating the emergence and survival of native plants such as sawgrass, wax myrtle, and perhaps other native plants in melaleuca invaded sites. Our findings showed that the effect of soils on seedling emergence and survival is variable and species specific. Adding seeds did not increase melaleuca seedling densities indicating that the plant was not seed lim- ited at these sites; while, the reverse was true with wax myrtle and sawgrass where seed addition increased seedling densities. Understanding the seed and seedling dynamics of the native plants of interest is one of the first steps to designing programs to rehabilitate ecosystems degraded by exotic plant invasions.

\section{ACKNOWLEDGEMENTS}

We acknowledge the technical assistance of Jorge Leidi and Reynaldo Moscat in USDA/ARS, Fort Lauderdale, Florida. We are particularly indebted to Christopher Grieshop and the AmeriCorps Volunteers program of the Student Conservation Association for assistance in establishing the permanent plots and help with data collection. We also acknowledge the constructive comments and criticism of the reviewers who helped improve the overall quality of this article. We thank Dade County Department of Environmental Resource Management for financial support and South Florida Water Management District and Florida Department of Forestry for providing research sites.

\section{REFERENCES}

[1] Facelli, J.M. and Pickett, S.T.A. (1991) Plant litter: Light interception and effects on an old-field plant community. Ecology, 72, 1024-1031. doi:10.2307/1940602

[2] Facelli, J.M. and Pickett, S.T.A. (1991) Indirect effects of litter on woody seedlings subject to herb competition. Oikos, 62, 129-138. doi:10.2307/3545257

[3] Facelli, J.M. and Pickett, S.T.A. (1991) Plant litter: Its dynamics and its role in plant community structure. Botanical Review, 57, 1-32. doi:10.1007/BF02858763

[4] Xiong, S. and Nilsson, C. (1997) Dynamics of litter accumulation and its effects on riparian vegetation: A review. Botanical Review, 63, 240-264. doi:10.1007/BF02857951

[5] Xiong, S. and Nilsson, C. (1999) The effects of plant litter on vegetation: A meta-analysis. Journal of Ecology, 87, 984-994. doi:10.1046/j.1365-2745.1999.00414.x

[6] Weltzin, J.F., Keller, J.K., Bridgham, S.D., Pastor, J., Allen, P.B. and Chen, J. (2005) Litter controls plant community composition in a northern fen. Oikos, 110 , 537-546. doi:10.1111/j.0030-1299.2005.13718.x

[7] Vázquez-Yanes, C. and Orozco-Segovia, E. (1992) Effects of litter from tropical forest on tree seed germination and establishment under controlled conditions. Tree Physiology, 11, 391-400.

[8] Thompson, K., Grime, J.P. and Mason, G. (1977) Seed germination in response to diurnal fluctuations of temperature. Nature, 267, 147-149. doi:10.1038/267147a0

[9] Koorem, K., Price, J.N. and Moora, M. (2011) Species specific effects of woody litter on seedling emergence and growth of herbaceous plants. PLOS ONE, 6, e26505. doi:10.1371/journal.pone.0026505

[10] Kostel-Hughes, F., Young, T. and Wehr, J.D. (2005) Effects of leaf litter depth on the emergence and seedling 
growth of deciduous forest tree species in relation to seed size. Journal of the Torrey Botanical Society, 132, 50-61. doi:10.3159/1095-5674(2005)132[50:EOLLDO]2.0.CO;2

[11] Molofsky, J. and Augspurger, C.K. (1992) The effect of leaf litter on early seedling establishment in a tropical forest. Ecology, 73, 68-77. doi:10.2307/1938721

[12] Carson, W.P. and Peterson C.J. (1990) The role of litter in an old-field community: Impact of litter quantity in different seasons on plant species richness and abundance. Oecologia, 85, 8-13. doi:10.1007/BF00317337

[13] Farrer, E.C. and Goldberg, D.E. (2009) Litter drives ecosystem and plant community changes in cattail invasion. Ecological Applications, 19, 398-412. doi:10.1890/08-0485.1

[14] Holdredge, C. and Bertness, M.D. (2011) Litter legacy increased the competitive advantage of invasive Phragmitis australis in New England wetlands. Biological Invasions, 13, 423-433. doi:10.1007/s10530-010-9836-2

[15] Jordan. N.R. and Larson, D.L (2008) Soil modification by invasive plants: Effects on native and invasive species of mixed-grass prairies. Biological Invasions, 10, 177-190. doi:10.1007/s10530-007-9121-1

[16] Martin, M.R., Tipping, P.W. and Sickman, J.O. (2009) Invasion by an exotic tree alters above and below ground ecosystem components. Biological Invasions, 11, 18831894. doi:10.1007/s10530-008-9366-3

[17] Dray Jr., F.A., Bennett, B.C. and Center, T.D. (2006) Invasion history of Melaleuca quinquenervia (Cav.) S.T. Blake in Florida. Castanea, 71, 210-225. doi:10.2179/05-27.1

[18] Rayamajhi, M.B., Van, T.K., Pratt, P.D. and Center, T.D. (2006) Temporal and structural effects of stands on litter production in Melaleuca quinquenervia dominated wetlands of south Florida. Wetlands Ecology and Management, 14, 303-316. doi:10.1007/s11273-005-1481-7

[19] Rayamajhi, M.B., Pratt, P.D., Center, T.D. and Van, T.K. (2010) Exotic tree leaf-litter accumulation and mass-loss dynamics compared with two sympatric native species in south Florida, USA. European Journal of Forest Research, 129, 1155-1168. doi:10.1007/s10342-010-0404-1

[20] Franks, S.J., Kral, A.M. and Pratt, P.D. (2006) Herbivory by introduced insects reduces growth and survival of Melaleuca quinquenervia seedlings. Environmental Entomology, 35, 366-372. doi:10.1603/0046-225X-35.2.366

[21] Rayamajhi, M.B., Van, T.K., Pratt, P.D., Center, T.D. and Tipping, P.W. (2007) Melaleuca quinquenervia dominated forests in Florida: Analyses of natural-enemy impacts on stand dynamics. Plant Ecology, 192, 119-132. doi:10.1007/s11258-006-9231-3

[22] Rayamajhi, M.B., Pratt, P.D., Center, T.D., Tipping, P.W. and Van, T.K. (2008) Above ground biomass of an invasive tree melaleuca (Melaleuca quinquenervia) before and after herbivory by adventive and introduced natural enemies: A temporal case study in Florida. Weed Science, 56, 451-456. doi:10.1614/WS-07-152.1

[23] Tipping, P.W., Martin, M.R., Nimmo, K.R., Pierce, R.M., Smart. M.D., White, E., Madeira, P.T. and Center, T.D. (2009) Invasion of a west everglades wetland by $\mathrm{Me}$ - laleuca quinquenervia countered by classical biological control. Biological Control, 48, 73-78.

doi:10.1614/WS-07-152.1

[24] Browder, J.A. and Schroeder, P.B. (1981) Melaleuca seed dispersal and perspectives on control. Proceedings of Melaleuca Symposium, Tallahassee, 23-24 September 1981, 17-21.

[25] Roblin, E. (1994) Alien invasive weeds-An example of national rivers authority sponsored research. In: De Wall, L.C., Child, L.E., Wade, P.M. and Brock, J.H., Eds., Ecology and management of invasive riverside plants, John Willey \& Sons, Chichester, 189-194.

[26] Rejmanek, M. and Richardson, D.M. (1996) What attributes make some plant species more invasive? Ecology, 77, 1655-1661. doi:10.2307/2265768

[27] Goodwin, B.J., McAllister, A.J. and Fahrig, L. (1999) Predicting invasiveness of plant species based on biological information. Conservation Biology, 13, 422-426. doi:10.1046/j.1523-1739.1999.013002422.x

[28] Hofstetter, R.H. (1991) The current status of Melaleuca quinquenervia in south Florida. Proceedings of the Symposium on Exotic Pest Plants, Washington DC, 159-176.

[29] Meskimen, G.F. (1962) A silvical study of the melaleuca tree in south Florida. Master Thesis, University of Florida, Gainesville.

[30] Rayachhetry, M.B., Van, T.K. and Center, T.D. (1998) Regeneration potential of the canopy-held seeds of melaleuca in south Florida. International Journal of Plant Science, 159, 648-654. doi:10.1086/297583

[31] Van, T.K., Rayamajhi, M.B. and Center, T.D. (2005) Seed longevity of Melaleuca quinquenervia: A burial experiment in south Florida. Journal of Aquatic Plant Management, 43, 39-42.

[32] Hastwell, G.T. and Facelli, J.M. (2000) Effects of leaf litter on woody seedlings in xeric successional communities. Plant Ecology, 148, 225-231. doi:10.1023/A:1009834425538

[33] SAS (1999) SAS, Version 8. SAS Institute Inc., Cary.

[34] Goldberg, D.E. and Werner, P.A. (1983) The effects of size of opening in vegetation and litter cover on seedling establishment of goldenrods (Solidago spp.). Oecologia, 60, 149-155. doi:10.1007/BF00379516

[35] Bueno, A. and Baruch, Z. (2011) Soil seedbank and the effect of needle litter layer on seedling emergence in a tropical pine plantation. Revista de Biologia Tropical, 59, 1071-1079.

[36] Guzmán-Grajales, S.M. and Walker, L.R. (1991) Differential seedling response to litter after hurricane Hugo in the Luquillo experimental forest, Puerto Rico. Biotropica, 23, 407-413. doi: $10.2307 / 2388259$

[37] Rasran, L., Vogt, K. and Jensen, K. (2007) Effects of litter removal and mowing on germination and establishment of two fen-grassland species along a productivity gradient. Folia Geobotanica, 42, 271-288. doi:10.1007/BF02806467

[38] López-Barrera, F. and González-Espinosa, M. (2001) Influence of litter on emergence and early growth of Quer- 
cus rugosa: A laboratory study. New Forests, 21, 59-70. doi:10.1023/A:1010623403834

[39] Hamrick, J.L. and Lee, J.M. (1987) Effect of soil surface topography and litter cover on the germination, survival, and growth of musk thistle (Carduus nutans). American Journal of Botany, 74, 451-457. doi:10.2307/2443821

[40] Peterson, C.J. and Facelli, J.M. (1992) Contrasting germination and seedling growth of Betula alleghanienesis and Rhus typhina subject to various amounts and types of plant litter. American Journal of Botany, 79, 1209-1216. doi: $10.2307 / 2445046$

[41] Myster, R.W. (1994) Contrasting litter effects on old field tree germination and emergence. Vegetatio, 114, 169-174.

[42] Rayamajhi, M.B., Van, T.K., Center, T.D., Goolsby, J., Pratt, P.D. and Racelis, A. (2002) Biological attributes of the canopy-held melaleuca seeds in Australia and Florida, US. Journal of Aquatic Plant Management, 40, 87-91.

[43] Reader, R.J. (1993) Control of seedling emergence by ground cover and seed predation in relation to seed size for some old-field species. Journal of Ecology, 81, 169175. doi: $10.2307 / 2261232$

[44] Urbieta, I.R., Perez-Ramos, I.M., Zavala, M.A., Maranon, T. and Kobe, R.K. (2008) Soil water content and emergence time control seedling establishment in three cooccurring Mediterranean oak species. Canadian Journal of Forest Research, 38, 2382-2393. doi:10.1139/X08-089

[45] Lucas-Borja, M.E., Fonseca, T., Parresol, B.R., SilvaSantos, P., Garcia-Morotea, F.A. and Tiscar-Oliver, P.A. (2011) Modeling Spanish black pine seedling emergence: Establishing management strategies for endangered forest areas. Forest Ecology and Management, 262, 195-202. doi:10.1016/j.foreco.2011.03.023

[46] Myers, R.L. (1975) The relationship of site conditions to the invading capability of Melaleuca quinquenervia in southwest Florida. Master Thesis, University of Florida, Gainesville.

[47] Wilsey, B.J. and Polley, H.W. (2003) Effects of seed additions and grazing history on diversity and productivity of subhumid grasslands. Ecology, 84, 920-931. doi:10.1890/0012-9658(2003)084[0920:EOSAAG]2.0.C $\underline{\mathrm{O} ; 2}$

[48] Wardle, G.M. (2003) Experimental determination of seed emergence and carry-over in the soil seed bank of the herbaceous perennial Trachymene incise (Apiaceae). Austral Ecology, 28, 161-172. doi:10.1046/j.1442-9993.2003.01258.x

[49] Garwood, N. (1983) Seed germination in a seasonal tropical forest in Panama: A community study. Ecological Monograph, 53, 159-181. doi:10.2307/1942493 